\title{
Global warming and the cosmopolitan political conception of justice
}

\author{
Aaron Maltais \\ This is an Accepted Manuscript of an article published by Taylor \& Francis in Environmental Politics. \\ Maltais, Aaron. 'Global warming and the cosmopolitan political conception of justice', Environmental \\ Politics, Vol. 17, No. 4, pp. 592-609. http://dx.doi.org/10.1080/09644010802193476
}

\begin{abstract}
Within the literature in green political theory on global environmental threats one can often find dissatisfaction with liberal theories of justice. This is true even though liberal cosmopolitans regularly point to global environmental problems as one reason for expanding the scope of justice beyond the territorial limits of the state. One of the causes for scepticism towards liberal approaches is that many of the most notable anti-cosmopolitan theories are also advanced by liberals. In this paper, I first explain why one of the strongest expressions of liberal anticosmopolitanism cannot simply be dismissed because it may fail to support desired environmental ends. The political conception of justice represents one of the most important challenges to cosmopolitanism generally and is thus a serious challenge to viewing global environmental problems in terms of cosmopolitan justice. Second I will show through the case of anthropogenic global warming that the political conception of justice under current conditions does have clear cosmopolitan implications despite its proponents claim.
\end{abstract}

\section{Introduction}

Within the literature in green political theory one can often find dissatisfaction with liberal theories of justice despite the fact liberal cosmopolitans regularly point to environmental degradation and its impacts as one reason for expanding the scope of justice beyond the territorial limits of the state (Pogge 1992: 63-64; Held 1997; 258-59). One of the causes for scepticism towards liberal approaches is that a number of the most notable anti-cosmopolitan theories are advanced by liberals (e.g. Rawls 1999a; Nagel 2005). Thus, liberalism does not clearly support the view that trans-border and global environmental problems generate the kinds of demanding political and distributive duties of justice that we normally associate with membership in a state, i.e. duties to accept a system of law and order, taxation to provide essential collective goods, a system for wealth re-distribution, and the dictates of democratically guided political institutions.

Many liberal thinkers view justice as largely or even exclusively about relations between people within existing coercive political orders, i.e. states (Rawls 1999b; Miller 1995; Blake 2001; Nagel 2005). On this view individuals and even states may still have certain environmental or even ecological moral duties. However, such general moral duties might not be demanding enough to support the broad economic, social, and political changes envisioned in much of what is prescribed in green political theory.

There are many characterisations of liberalism in green political thought that liberals would consider unfair. One finds the claim, for example, that liberalism entails giving preference to the interests of consumers and markets over other kinds of interests; or makes sharp distinctions between the public and the private realms; or is concerned largely with rights and 
only secondarily with duties (Dobson 2003: 33-87; Wissenburg 2006: 20-23). Each of these supposed features of liberalism is thought to weaken the basis for requiring of individuals that they take full responsibility for their environmental impacts.

However, it is clear that liberal theories of distributive justice are not foundationally committed to maximizing consumption or even economic growth (Rawls 1999b; Gaspart and Gosseries 2007), liberal feminist thinkers have shown in compelling ways that a coherent liberalism cannot use appeals to individual liberty/autonomy to blindly support a stark and supposedly 'natural' distinction between public an private concerns (Okin 1989), and there does appear to be room within a liberal framework for demanding other regarding duties of justice as first-order concerns, especially following Kantian liberal thought. Still, I think we can in part understand the above concerns as rooted in the correct perception that, following a liberal framework, it is not yet clear that environmental problems over borders and generations give rise to duties of justice comparable to the demanding duties of egalitarian justice liberals argue pertain between citizens of nation-states.

In what follows, I first explain why one of the strongest expressions of liberal anticosmopolitanism, what Thomas Nagel calls the 'political conception of justice' (Nagel 2005: 121) cannot simply be dismissed by cosmopolitans because it may fail to support desired environmental ends. The political conception of justice represents one of the most important challenges to cosmopolitanism generally and is thus a serious challenge to viewing global environmental problems in terms of cosmopolitan justice. Second, I will show through the case of anthropogenic global warming that the political conception of justice under current conditions does have clear cosmopolitan implications despite the claims of its proponents.

I will argue that if one rejects severe partiality for the interests of the current generation the political conception of justice does entail a duty to create a new global political project to address anthropogenic climate impacts. This is because addressing global warming requires global institutional arrangement(s) that can overcome the exceedingly difficult collective action problems both between states and between generations that currently make mitigation efforts so difficult to achieve. Thus, it is only by engaging in the kind of global political project that can credibly overcome these collective action problems that we could choose to act in a way that is not unjustifiably partial to the current generation's interests. The proposal is not for a global government but does require the creation of a supranational political arrangement that changes the authority structures of existing states.

My aim is not to advance a complete theory of our distributive duties of justice to future generations. Rather, the point I want to make is that one need only accept that we must show more than no concern for the interests of future generations in order to generate demanding cosmopolitan duties of political justice. More generally, the paper shows that just as a focus on gender has been used by liberal feminists to demonstrate that a coherent liberalism cannot lazily adopt socially accepted distinctions between the public and the private, a focus on environmental interconnectedness shows that liberals cannot simplistically limit the scope of demanding duties of justice to those that share in an existing coercive political order.

\section{Cosmopolitan justice and the challenge from the political conception}

The central argument of contemporary cosmopolitan political thought is that the demands of justice must be decoupled, at least to some degree, from the territorial bounds of the state. Within the global justice literature it is liberal cosmopolitans that have advanced the strongest arguments for this expansion of the scope of justice based on new kinds of global interconnectedness. Changes in the intensity and impacts of global trade and other forms of globalisation are thought to create a set of conventions, institutions and patterns of interaction that constitute, following John Rawls' terminology, a 'global basic structure' (in his domestic 
theory Rawls describes the 'basic structure' of political society as the institutional arrangements that are responsible for the distribution of rights and duties and those that have a significant impact on the distribution of advantages from social cooperation; Rawls 1999b: 6). This global basic structure must be justifiable to those affected by it which in turn, it is argued, means that relations at the global level can be subject to principles of justice in the same way relations within a state are, or should be (Beitz 1999). Appealing to changes in how we affect each other over state borders is only one of several ways in which cosmopolitan theories of justice are advanced. However, the argument from interconnectedness fits well with the view that when problems of environmental damage become trans-boundary or truly global in scope this interconnectedness also expands the scope of justice.

In opposition to the cosmopolitan thesis, the political conception of justice follows Rawls in viewing egalitarian distributive and political justice as existing between individuals only when they share in the kind of strong political association embodied by the state (Rawls 1999a). At the same time the political conception is distinct from Rawls' thinking in his The Law of Peoples because it maintains the premise of seeing individuals and not groups (i.e. societies or peoples) as the basic unit of concern (Nagel 2005: 135). Thus the political conception does not adopt the more contentious position that peoples' interests in political autonomy place a principled limit on the scope of justice; rather what is important is that the state represents a coercive legal order. Egalitarian distributive and political justice is activated within states only as part of what is needed to justify the non-voluntary and coercive nature of the state to individuals as moral equals (Blake 2001: 289).

On the political conception of justice, citizens of states are expected to accept the authority of the state because political order is needed to ensure the realisation of essential collective goods such as security, reliable welfare through collective productiveness, and protection of individuals' rights. All those that benefit from the state depend on their fellow citizens to underwrite this political order, and it is this kind of interdependence that gives rise to the demands of justice. In order to justify the limits on individual liberty involved in political society each subject should be given equal concern in determining the fair distribution of the goods and burdens produced by this system of cooperation (Nagel 2005: 128-30). This theory is one of the most important challenges to liberal cosmopolitanism because it appears to justify limits on the scope of justice along what are admitted to be arbitrary political boundaries. Furthermore, it does this by appealing to premises and arguments widely shared by liberals; namely (1) the notion of individual moral equality, (2) the moral significance of reciprocity and (3) the view that our relations with others should as far as is possible be founded in consent.

The first two strengths of the political conception are made apparent in the way it appeals to the familiar liberal notion of fair reciprocity. It is fair reciprocity among those that must accept the type of coercive regulation found within the state that gives both content to demanding duties of justice and dictates their scope. This kind of fair reciprocity simply does not apply between members of different states because they do not share in a coercive political structure. For example, the global trade regime should meet a standard of fairness that is appropriate to these kinds of relations between states, but this standard of fairness will not be the egalitarian standards of social justice that are owed among individuals within a single political order. The argument seems to undercut the main idea driving 'associative cosmopolitan' ${ }^{1}$ theories, which is to draw a parallel between domestic and international conditions and then to appeal to the primacy of the individual perspective over the interests of states, peoples, or cultures.

On the political conception of justice, the cosmopolitan's parallel does not focus on what in fact generates duties of egalitarian justice between a set of individuals, namely the kinds of coercive political institutions we find in states. Thus the first strength of the theory is that it is 
an individualistic and universalistic theory built on the premise that individuals are inherently morally equal while it can still maintain an anti-cosmopolitan stance. The second strength in the theory is in the way is appeals to reciprocity. Fair reciprocity is central to the standard argument within liberal political thought for why we should accept the demandingness of duties of justice within the state (Klosko 2005: 75-92). On the political conception the argument for reciprocity gets off the ground as soon as individuals contribute their part to underwriting the political authority of the state. Because individuals outside of the state are not asked to underwrite a state's political authority or to accept its dictates in the manner insiders are, liberals moved by the justificatory force of fair reciprocity should also see the moral forces of treating relations within the state differently than those over state borders (Waldron 1993).

The cosmopolitan could plausibly argue that some contemporary forms of global governance, such as the World Trade Organization (WTO), impose limits on what states can do and that these arrangements are more extensive than simple treaties between states (see Risse 2006: 682-683). However, in defending different standards between the state and global realms, the political conception of justice is pointing to actual differences between states and global institutional arrangements as the morally relevant ones for when demanding duties of egalitarian justice are appropriate (Nagel 2005: 140). A state's claim to political legitimacy means that it is thought to have the moral authority to use coercive force to ensure that individual residents do what is required of them so as to secure the political order on which members depend (e.g. obey the law and pay taxes). The political community of a state is thought to have legitimate claims against individual members so that the state can in a direct way dictate the content of individuals' support for the political order and the content of individuals' rights and duties in a large number of ways. The WTO simply does not claim for itself this kind of political legitimacy (Risse 2006: 681-92).

In the WTO there is no pretence of moral authority to use coercive force so as to ensure that all states (1) support the collective project in the first place or (2) continue to support it. Even though it may be enormously costly, there is no political duty on the part of states to support the WTO beyond what they have consented to through agreements with other states and each state can unilaterally choose to exit the WTO (Article XV of the WTO). Moreover compliance mechanisms within the WTO framework are unlike those exercised by the state. Members of the WTO do not collectively underwrite authoritative dictates that are given and implemented by the WTO over its members. Instead when there is a conflict between WTO members it is resolved through a judicial process that is more like arbitration, and when sanctions are imposed they are imposed by one party to a WTO dispute process upon another (Annex II of the WTO Agreement: Understanding on rules and procedures governing the settlement of disputes).

This takes us to the third important way in which the political conception challenges liberal cosmopolitanism. Those that advance the political conception of justice must provide a 'nonvoluntarist' justification (i.e. a justification that is not founded in what subjects have consented to) for the political duties individuals are thought to have within states. This is because the overwhelming majority of people never actively give their consent to the state's authority in a morally relevant way (Simmons 1979: 57-100, Wellman 2001: 735-740). However, their position also supports the view that expansions of the scope of our political duties should be voluntary. Nagel notes several reasons for why global forms of political authority would be desirable, including the provision of the global public good of climate change mitigation (Nagel 2005: 144). Yet any such supranational form of political association would also lead to legitimate demands for egalitarian standards of justice at the global scope, and Nagel argues that individuals or political communities cannot be 'morally obliged to expand their moral vulnerabilities in this way' (Nagel 2005: 144). 
Nagel goes on to state that:

Justice is something we owe through our shared institutions only to those with whom we stand in a strong political relation.... If we find ourselves in such a relation, then we must accept the obligations, but we do not have to seek them out, and may even try to avoid incurring them (Nagel 2005: 121).

The position, here, is one of non-voluntarism for existing states (or at least those states that are minimally just) but voluntarism for any new institutional arrangements of this kind. Treating the two cases differently should have strong appeal within liberalism because it is based on the notion that our commitments to others should, as far as is possible, be founded on voluntary consent. Following existing interpretations of the political conception of justice the choice to limit political legitimacy to the state or expand it to supranational institutions actually can be offered (e.g. Risse 2006).

\section{The cosmopolitan political conception of justice}

In what follows I will argue for an associative duty to create a new form of political authority at the global scope so that we can both make collective decisions on how to address the problem of global warming and credibly enforce these decisions. Unlike many liberal cosmopolitans, I do not defend this claim by pointing to how the existing global order is increasingly comparable to existing domestic orders. Instead I point to the way in which the problem of anthropogenic global warming has bound us together worldwide in a morally distinct way. In particular, we now face a set of exceedingly difficult global collective action problems both between states and between generations that give rise to a duty of justice to create a new global political project to address the human impact on our climate.

This argument parallels the argument in liberal thought generally for why we should have states in the first place. Because of the effects we can have on each other, our ability to achieve human goods at all is dependent on solving a host of collective action problems by creating and/or supporting a political order that can secure essential collective goods such as collective security. Following the political conception of justice, there is something distinct about such a political order that gives rise to far-reaching demands of justice. I will argue that following the logic of the political conception of justice distinctive kinds of interconnectedness at any scope can give rise to far-reaching demands of political justice.

The political conception of justice is dependent on what can be called the 'collective goods justification' of the state, i.e. the claim that we need the state to provide a set of goods that are necessary to virtually all individuals' wellbeing such as a secure and orderly society and protection of our rights and property. Without a state, it is argued, such goods cannot be provided, will be underprovided, or will not be provided in a just way (for a good summary of the arguments in this tradition of thought that covers much of the relevant literature see Klosko 2005: 17-59). I will argue that following the logic behind the claim that individuals have non-voluntary duties to support existing minimally just states we should also recognise a non-voluntary duty to create and support a new form of global political authority that could enforce collective decisions on how to address the problem of global warming. In other words, this political duty exists by virtue of how we are interconnected with others independently of the kinds of political arrangements we currently are members of or consensually enter into. 


\section{Global warming, collective action, and global political authority}

Despite significant disagreement among economists on the most efficient level and timing of investment in global warming mitigation, research increasingly points to the conclusion that mitigation costs, while not inconsiderable for existing and proximate generations, are (1) at least manageable (IPCC 2007b: 16) and (2) will be outweighed by the benefits over the longer term, assuming that associated mitigation policies help prevent dangerous levels of global warming in the expected fashion (Stern 2007: viii-xiv; Nordhaus 2007: 15-19). At the same time, the message coming for economic research is that such an efficient effort to mitigate global warming will require a common, coordinated and a nearly global system for putting a price on green house gas (GHG) emissions, especially for $\mathrm{CO}_{2}$. This could be done either directly by way of setting a price/tax for emissions or by setting emissions caps and trading emissions permits. Without such coordinated global policies the costs of mitigation will rise dramatically (Nordhaus 2007: 69-73), and the prospects for avoiding dangerous climate change will be considerably worsened.

Despite such positive economic analysis, persuasive research in international relations and international political economy on global warming points to the conclusion that states will not be able to implement coordinated policies that will lead to large scale levels of GHG emissions reductions via international agreements like the Kyoto Protocol (Barrett and Stavins 2003; Sandler 2004: 212-234; Finus et al. 2006). Here the evidence points to a lack of incentives for states and even the current generation as a whole to take on the costs created by policies that would meaningfully reduce GHG emissions (Gardiner 2001, Barrett 2005). The prediction above is based on the idea that providing the good of global warming mitigation generates a global public goods collective action problem.

Collectively investing in climate change mitigation is said to be worth the cost but at the same time agents cannot be excluded from the positive effects of others' investments in GHG emissions reductions. Because it is the sum of total global reductions in GHG emissions (and not where these reductions take place) that has an effect on climate conditions individuals, companies, and states all have self-interested reasons to free-ride by letting others take on the costs of mitigation while they themselves continue to enjoy the benefits of those activities that cause atmospheric pollution. When individual agents act on this reasoning they will collectively fail to adequately provide the public good and/or fail to protect the 'common pool resource' of climate security. Common pool resources are valuable goods, often natural, where users have relatively unrestricted access to exploit and/or deplete the resource. Collectively users may be best served by sustainably using the common pool resource (e.g. fisheries), however they may also be unable to successfully cooperate with each other to achieve this end when open access makes it rational for each individual to maximise their own short-term exploitation of the resource. When the difficulties in protecting a common pool resource genuinely has the character of a 'tragedy of the commons' collective action problem (Hardin 1968), what is required is some system of political authority that can manage access to the common pool resource and enforce rule violations in such a way that cooperation and not free-riding becomes the dominant strategy.

Providing collective goods at the global level (e.g. preventing the spread of disease, efficiency gains in global trade, or protection of the atmosphere's ozone layer) is not necessarily underprovided simply due to the absence of global forms of political authority. However, preventing damaging levels of GHG emissions is thought to be an example of a global public good where this result is to be expected. GHG emissions, especially $\mathrm{CO}_{2}$, are associated with nearly every sector in our economies. This means that there are a wide variety of actors with varying kinds of interests in the activities associated with depletion of the atmospheric commons. Having many actors that are often remote from each other and that 
have different kinds of interests in relation to the common pool resource we are trying to protect makes it less likely that interested parties can successfully cooperate on voluntary terms without the interference of coercive political institutions (Ostrom 1990: 183-84; Cornes and Sandler 1994). Furthermore, states are expected to have different cost-benefit expectations in relation to mitigation and some states may even expect that they will benefit from climate change at least over the shorter term. The above features further give us reason to be pessimistic about the ability of states to successfully cooperate through voluntary international agreements (Sandler 2004: 221-225; Barrett 2004: 41-42).

If the description offered above is accurate we would expect any treaty actually achieved to be hampered by non-participation, very weak emissions targets, failures to meet targets, delaying of emissions cuts to the future, and a lack of enforcement mechanisms. Each of the expectations is descriptive of the current climate treaty (Böhringer and Finus 2005). The problem with Kyoto-type international agreements is that when it is collectively rational to cooperate, but not individually rational for states to do so, effectiveness in achieving collective goals and the self-enforcement employed in these kinds of voluntary agreements are undermined. Yet given what appear to be huge payoffs for cooperation should we not be much more optimistic about the likelihood that sovereign states will be able to successfully implement agreements to protect the commons?

Large payoffs may give states an interest in acting unilaterally or in small groups to gain access to large future pay-offs by encouraging broader cooperation. What appears to be a global prisoner's dilemma might actually be a different kind of collective action problem where successful provision, cooperative or otherwise, is possible in the existing state system. However, the problem is not only that cooperation between states on a certain abatement target represents a difficult collective action problem but that there is also a severe cooperative challenge between generations (Gardiner 2001: 402-16). In short, the cumulative nature of atmospheric pollution, and long time lags before we see the full impacts of mitigation efforts, means that any costs we take on now will benefit future generations much more than they could benefit us.

What is required is a dramatic response over the short term that turns around a powerful trend of increasing emissions. It is expected that on current trajectories total global $\mathrm{CO}_{2}$ emissions will be 55\% higher than today's levels already by 2030 (International Energy Agency 2006: 78). At the same time the IPCC claims that keeping global mean temperature increases below $2.5{ }^{\circ} \mathrm{C}$ (i.e. in relation to the pre-industrial baseline) will require $\mathrm{CO}_{2}$ emissions to be reduced to by $50-85 \%$ below 2000 levels by 2050 (IPCC 2007b: 23). Meanwhile the desired effects in terms of temperature stabilisation occur relatively far into the future, and stabilisation of some of the most important negative impacts arrive in the distant future. The point in time when the benefits of mitigation politicise outweigh their costs can actually be quite far into the future (Kavuncu and Knabb 2005).

As Stephen Gardiner puts it, climate change entails an 'intergenerational' tragedy in addition to the 'intragenerational' one because what is collectively best in terms of selfinterest for the current generation as a whole is to avoid reducing GHG emissions (Gardiner 2001: 403-04). Even more troublesome, Gardiner notes that given a situation where past generations have not engaged in significant mitigation:

The same reasoning will apply to each future generation as it comes into being. However much it may deplore the effects of the previous generations decisions on it, each generation will face the same decision situation with respect to generations later than it' (Gardiner 2001: 404). 
If each generation acts on its rational self-interest we will be stuck on the path of inaction and the human race will behave in a way that will dramatically worsen the environmental conditions for its own wellbeing.

Both theoretical analysis and evidence of the comparatively poor success of efforts to provide the good of global warming mitigation is comparison to other global collective goods like ozone protection (Sandler 2004: 212-234; Barrett 2005; Sunstein 2007) support the view that the climate change problem is not less difficult to resolve than the coordination problems used in the liberal tradition to justify the need for political society but at least equally problematic, if not rather more problematic. The claim is not that the global warming mitigation collective action problem is worse than a prisoner's dilemma. Rather, because of the intergenerational character of the problem, existing agents may not only have an interest in free-riding on the efforts of others but they may also lack the strong preferences for the collective provision of climate change mitigation that are normally found for classic public goods like collective security and national defence (Maltais 2008: 95-107).

The chief barrier we have identified to a programme of aggressive global GHG emissions reductions is the lack of a global system for enforcing emissions targets or coordinated global instruments to put prices on GHG emissions. A globally coordinated system that can generate costs/prices on GHG emissions and has strong compliance mechanisms will limit the sovereignty of states in ways states are not currently limited. In other words, we appear to need some new supranational form of political association if we are to overcome the collective action problems that currently make meaningful reductions in total global levels GHG emissions so hard to achieve. Note that I focus on mitigation and not adaptation because I suspect that the prospects for collectively providing the good of global warming mitigation may be better than the prospects for wealthy states to invest significantly in adaptation efforts in poor countries. However it is beyond the scope of this paper to address this issue. See the contribution of Jagers and Otterström elsewhere in this volume for a more detailed analysis of the ethics of adaptation.

Thus far we can identify a couple of reasons for thinking that the problem of climate change speaks for a global political solution. Climate change has the real potential to threaten the basic security and welfare of humanity (IPCC 2007a: 7-16), but it is unlikely that we will overcome the collective action problems that currently make achieving mitigation so difficult without some form of global political authority. Yet, all this tells us is that if we do in fact have duties to take decisive action in the case of climate change we must work towards such global political institutions. What reasons could we give following the premises employed in the political conception of justice to show that we do now have duties of justice to enter into a global political project to address the problem of climate change?

\section{Global warming and our natural duties of justice}

The most straightforward normative reason to create the institutional conditions necessary to achieve a coordinated strategy for radically reducing GHG emissions is to argue that we have a duty to future generations to take on these costs. A commitment to the equal inherent moral worth of all individuals certainly appears to entail that we have duties to future generations. However, this intuition is itself questionable and there is considerable debate over how demanding our duties to future generations are if we do in fact have them (see Page 2006: 50160). I will not try to give an answer on what our duties to future generations actually are. Instead I argue that because of the kind of threat global warming entails it is morally required to create those institutional conditions through which we could act collectively to mitigate global warming. We can establish such a duty to support a supranational form of political authority by appealing to two different kinds of other-regarding reasons. The first reason is 
based on the minimalist view that we owe future generations more than no consideration whatsoever. The second reason for action is founded in reasonable disagreement over our obligations to future generations.

My argument is based on the position that there is at the very least a 'natural duty of justice' (Rawls 1999b: 100) to create the institutional conditions that make it possible to formulate an active and collective choice about what burdens we are willing to take on for the sake of future generations. The natural duty of justice is the foundational argument in the political conception of justice justifying the political authority exercised by states to individual subjects and justifying their political duties within these political communities (Rawls 1999b: 99-100; Nagel 1991: 33-40; Waldron 1993). The first thing to note about the natural duty theory of political duties is that it does not appeal to consent in justifying these duties.

In existing states direct consent cannot be the foundation for political obligations because the overwhelming majority of people never actively consent to their state's authority or their own political duties but are instead born into political orders that make such demands on individual members. Indirect tacit consent through the 'choice' to reside in a certain state also fails to be a plausible source for political obligations. This is because we never have the opportunity to consent to the territorial scope of existing states and our attachments to specific territories and communities are themselves unchosen (Simmons 1979: 57-74, 95-100). Because states do not seek consent for the scope of their authority Christopher Heath Wellman notes that they have 'no right to insist that citizens must play by the state's rules or leave' in trying to establish residents' tacit consent (Wellman 2001: 736).

Given these well known problems with consent based justifications of political obligations, a common liberal argument is to claim that because we all benefit from political society to various degrees fairness demands that we all contribute to supporting this cooperative venture. Clearly the voluntary acceptance of benefits can generate duties of fair reciprocity, but many of the benefits of political society are not benefits we can easily avoid. This makes it difficult to establish that we have actually accepted benefits (Simmons 1979: 138-9). We should expect most individuals to see many of the benefits of the state as worth their cost. However, given the non-voluntary nature of our membership in the state it is dubious to claim that most actively accept all the collective goods the state provides or that individuals have a realistic exit option from just those aspects of the state that they would rather not support. ${ }^{2}$

At the same time, there is a serious theoretical difficulty with grounding political duties on the non-voluntary receipt of benefits. As Nozick famously agues, such a principle would result in the highly paternalistic and sometimes absurd view that individuals have duties to support all kinds of ventures that happen to benefit them simply because some group of people decided to implement the venture (Nozick 1974: 93; Simmons 1979: 147-152). Liberals will want to avoid such paternalism when justifying political duties in existing states but cannot do so by arguing that individuals only have political duties of fair reciprocity when they actively accept some collective good. In states as we know them the content of each citizen's political duties are not something they dictate unilaterally to the rest of the political community by selecting the parts of the collective political project they want to participate in and what parts they want to avoid (Wellman 2004: 109-11).

There remains another non-paternalistic way to appeal to the benefits of political society in establishing a duty to contribute to this collective political project, a duty to accept the demands of political society because others depend on this system for achieving human goods (Wellman 2001, p. 744). Because Rawls recognized the difficulties with the received benefits approach he abandoned the idea of founding our political duties simply in fair reciprocity and instead appealed to the Kantian idea of a natural duty of justice, which is an other regarding 
duty 'to support and to comply with just institutions that exist and apply to us. It also constrains us to further just arrangements not yet established' (Rawls 1999b: 99).

Recognizing that political society is a cooperative project with clear benefits over conditions in the absence of political order we can expect that individuals will have many rational self-interested reasons to accept political conventions and obey the state. Yet at the same time this self-interested form of reciprocity does not amount to a political obligation and will invariably fail to motivate in many cases for all individuals living in large scale modern societies (Buchanan 1990). Still many individuals will also have an other-regarding moral reason to support this collective political project because on their considered judgements they do accept the benefits of political society on the premise that they are members of a cooperative venture. This is an other-regarding as opposed to strictly self-interested form of reciprocity (i.e. fairness). However, it is not enough to establish general political obligations in a non-voluntary state because many will not, at least on some occasions, relate to the demands of political society in a way that could generate obligations of fairness based in the active acceptance of benefits.

When other-regarding reciprocity fails to explain why we should insist that individual subjects have demanding duties of justice within the state what remains is a natural otherregarding duty to support the state as a cooperative venture because others depend on it. On this view, the only way to secure meaningful security, rights and freedoms is from within a political system. This fact combined with the negative effects each one of us can have on others in the absence of a political system generates for every individual a moral duty to join and/or support political society (Kant 1965: 60-76; Waldron 1993). The idea is that it is unreasonable and morally objectionable to act in a way that prevents others from securing the benefits of political community. This justification of political duties is founded in the contractualist reasoning that treating others as our moral equals requires of us that we accept a set of demands (i.e. political duties) that are necessary for the proper functioning of political society. Self-interest and fairness still do work in giving individuals reasons to accept the demands of political society, but the natural duty of justice is necessary at a foundational level to establish that we have the range of political duties associated with membership in existing states thought necessary to secure essential collective goods.

The natural duty of justice has been used by some of its main supporters, like Rawls and Nagel, to defend the position that individuals have special ties to their own states and special duties of justice to fellow citizens to the exclusion of other states and non-members. We have non-voluntary and demanding political duties to our compatriots even though it is recognised that state boundaries are in important respects arbitrary because others depend on the persistence of political order within our shared territorial space. Likewise, the benefits of a specific political order are legitimately limited to fellow citizens because its successful functioning is dependent on such limits (Waldron 1993; Rawls 1999a). For relations at the global level, Nagel argues that

\footnotetext{
Without the enabling condition of sovereignty to confer stability on just institutions, individuals however morally motivated can only fall back on a pure aspiration for justice that has no practical expression, apart from the willingness to support just institutions should they become possible. The other-regarding motives that support adherence to just institutions when they exist do not provide clear guidance where the enabling conditions for such institutions do not exist, as seems to be true for the world as a whole (Nagel 2005: 115-16).
}

However, Nagel's position that we cannot have moral obligations to expand the scope of our demanding duties of justice does not appear to be compatible with the natural duty theory of political duties.

If we have a general natural duty to support the political orders others depend on, and the specific problem we face at the global level is a lack of just institutions that others need, it 
does not make sense to say that we have no clear guidance on what to do to satisfy our otherregarding motives. Clearly, the answer is that we should create the needed political institutions. Our aspiration for justice is not thwarted by the lack of the right kinds of institutions because we are not powerless in their absence. Political order is not just something we must relate to, it is also something we can actively create.

Possibly what Nagel intends is that limited supranational forms of political authority are not possible and that the only possible form of global political authority is a global state. Then maybe the 'enabling conditions' do not and could not exist, nor is it clear that such a development could ever be desirable. Yet the idea that it would be impossible to implement a system of divisible sovereignty with both supranational and state level forms of political authority does not appear to coincide with empirical evidence (Philpott 2001; Osiander 2001: 281-84). Much more plausibly the liberal anti-cosmopolitan might say that there is simply a lack of political will to create the proposed institutional arrangement. However, it is not normatively accurate to say that when there is a lack of political will our moral motivation lacks a framework through which we could act. Instead, what is really happening is that we are failing in our natural duty of justice to create the appropriate framework.

To defend coherently the idea of a natural duty of justice to existing political institutions one must also accept the possibility that there can arise duties to support the creation of just institutions that ought to apply to us, even at the global level. On the political conception of justice, accepting the state's authority and duties of justice to fellow members is simply to accept the 'conditions of peace and a legal order, with whatever community offers itself,' (Nagel 2005: 133). For the case of climate change, we have seen that the only community that can 'offer itself' is a global one. Given the kinds of affects we are having on each other globally, and the kind of global collective action problems generated by climate change, we are associated with each other politically at the global level even in the absence of political institutions. What remains to be shown is that respecting others as our moral equals does give us reason to at least create the conditions from which we could do something about the human impact on our climate. I will argue that this appears to be true both in relation to future generations and in relation to our contemporaries.

\section{Future generations}

If we create the global institutional conditions through which we could make collective decisions on how to react to the threat of global warming it would be more difficult to pursue a policy of polluting now without limit and letting future generations suffer the consequences. Given such a global political arrangement, inaction would require a much more overt policy of endangering the environmental conditions necessary to sustain human welfare in the future than the current process of obscured inaction via weak global accords (Gardiner 2006). Of course, if the egoistic approach prevails future generations will suffer no matter what kind of institutional arrangements we have. Nonetheless, my argument is that we owe it to future generations to at least make the option to take the drastic changes required to address anthropogenic climate change politically available.

Non-support for the institutional conditions through which we could act collectively to mitigate global warming amounts to indirectly taking a strongly partialist stance in relation to future peoples' interests. This level of partialism is incompatible with the contractualist reasoning on which the political conception is based, ${ }^{3}$ which offers compelling arguments for rejecting strong partialism as a basis for determining what we owe to others (Nagel 1991, Scanlon 1998). If we are to claim credibly that we are making active choices based on assessments of our moral obligations to future generations then the mitigation option must be 
made available. An important objection to this line of reasoning is that I have not established a clear enough picture of our obligations to future generations to support such a radical proposal. Yet, even accepting that there is significant uncertainty and debate over what is morally required of us intergenerationally this reasonable disagreement speaks for, not against, a global political project.

\section{Contemporaries}

A second 'other regarding' argument in support of my thesis is that no single country or group of countries can legitimately undermine efforts to create the conditions necessary for the rest of the world to makes choices about how to deal with the threat of global warming. Political legitimacy over whether or not to pollute aggressively the Earth's atmosphere already resides at the global level. The unwillingness of a political community to address the potentially devastating effects they, together with other peoples, can have on the environment cannot be justified to others by appealing to the moral significance of state sovereignty any more than an individual's unwillingness to contribute to a system of collective security within their political community can be justified to others simply by appealing to their own liberty claims. If we accept the normative justification underlying individuals' non-voluntary duties within the state then we should also accept that individuals have a non-voluntary duty to support the creation of a global political order (i.e. through their respective states) that does not currently exist but that ought to apply to them. A commitment to the moral equality of our contemporaries requires that we engage in a political project with all others, not just those within our own states.

Note that, even if some states are reducing or limiting their own emissions, refusing to support a global project still amounts to a failure to live up to one's global natural duties of justice. In the domestic case, not violating others' rights is not sufficient to satisfy our otherregarding duties because in order to secure essential collective goods there must be a political order with authority over the vast majority of individuals within any given territory. Doing our part means accepting a set of non-voluntary and demanding duties of justice because it must be up to the state to dictate when and how individuals contribute to the collective political project if it is to fulfil its function (Wellman 2004). The same holds in the global warming case. Satisfying our natural duties of justice requires that we accept the authority of a global arrangement because it is this kind of political order we need if we are to address adequately the problem of climate change. Supporting this global political project is what it means to actually do something about the collective action problems involved in addressing the human impact on our climate.

\section{Conclusion}

Because I have not addressed how the global political project I propose will be designed institutionally, or the more familiar debates addressed elsewhere in this volume about how the costs of mitigation should be distributed, I have not said very much about what global justice demands in the case of global warming. What I have defended is the normative case for a truly global political project to address global warming. On the more familiar questions about distributive justice what I can note is that once a supranational form of political authority is in place this political institution will need to be justifiable to those that are subject to it. Thus, there will be reason to recommend standards of political justice that meet some measure of fair representation and standards of distributive justice based on the fair allocation of burdens in implementing emissions reductions, should we happen to choose this policy. 


\section{Acknowledgements}

An earlier version of this article was presented to the ECPR Joint Sessions Workshop 'Democracy the Day After Tomorrow' held at the University of Helsinki, 7-12 May 2007. I would like to thank the discussant for my paper, Sverker Jagers, and the participants at this conference for their useful comments. I would also like to thank Ludvig Beckman, Edward Page, and an anonymous referee for Environmental Politics for their constructive suggestions.

\section{Notes}

1. Associative cosmopolitanism is the view that a shared and equal moral status among all individuals combined with certain forms of global association can give rise demanding duties of global justice. This perspective can be contrasted with 'non-associative cosmopolitanism' where individuals' equal and shared moral status is on its own sufficient to generate demanding duties of global justice.

2. There is a temptation for liberals attracted to the fairness approach to abandon the requirement that benefits be voluntarily accepted and instead to appeal to hypothetical consent. Yet few accept that hypothetical consent can generate real obligations in the same way actual consent can. Thus, in hypothetical consent theories it is not consent but some other moral consideration that is generating political duties (Dworkin 1975: 17-21).

3. This very weak position on obligations to future generations still may run afoul of the non-identity problem, according to which we cannot harm those that will actually come into existence in the future by polluting the atmosphere as we see fit because these choices, whatever they are, will dictate which future people come into existence (Parfit, 1984: 351ff; Page 1999). The contractualist theorists I am criticising are unlikely to see an appeal to non-identity reasoning as a promising avenue for rejecting the argument presented here, but to make the argument more persuasive the non-identify problem will need to be addressed. For a strong contractualist argument against the moral force of the non-identity problem see Reiman 2007; and Heyward's contribution to this volume.

\section{References}

Babiker, M. H., Jacoby, H. D., Reilly, J. \& Reiner, D. M., 2002. The Evolution of a Climate Regime: Kyoto to Marrakesh and Beyond. Environmental Science \& Policy 5,195206.

Barrett, S., 2004. Critical Factors for the Successful Provision of Transnational Public Goods. Stockholm: Sweden, Secretariat of the International Task Force on Global Public Goods.

Barrett, S., 2005. Environment and statecraft: the strategy of environmental treaty-making (paperback edition). Oxford: Oxford University Press.

Barrett, S. \& Stavins, R., 2003. Increasing Participation and Compliance in International Climate Change Agreements. International Environmental Agreements: Politics, Law and Economics, 3, 349-376.

Beitz, C. R., 1999. Political Theory and International Relations. Princeton, NJ: Princeton University Press.

Blake, M., 2001. Distributive Justice, State Coercion, and Autonomy. Philosophy and Public Affairs, 30 (3), 257-296. 
Böhringer, C. \& Finus, M., 2005. The Kyoto Protocol: Success or Failure. In: Helm, D., ed. Climate-change Policy. Oxford: Oxford University Press.

Buchanan, A., 1990. Justice as Reciprocity versus Subject-Centered Justice. Philosophy and Public Affairs, 19 (3), 227-252.

Cornes, R. \& Sandler, T., 1994. Are Public Goods Myths? Journal of Theoretical Politics, 6 (3), 369-385.

Dobson, A., 2003. Citizenship and the environment. Oxford: Oxford University Press.

Dworkin, R., 1975. The Original Position. In: Daniels, N., ed. Reading Rawls. New York: Basic Books.

Finus, M., Van Ierland, E. \& Dellink, R., 2006. Stability of Climate Coalitions in a Cartel Formation Game. Economics of Governance, 7 (3), 271-291.

Gardiner, S. M., 2001. The Real Tragedy of the Commons. Philosophy and Public Affairs, 30 (4), 387-416.

Gardiner, S. M., 2006. A Perfect Moral Storm: Climate Change, Intergenerational Ethics and the Problem of Moral Corruption. Environmental Values, 15, 397-413.

Gaspart, F. \& Gosseries, A., 2007. Are generational savings unjust? Politics, Philosophy \& Economics, 6 (2), 193-217.

Hardin, G., 1968. Tragedy of the Commons. Science, 162, 1243-1248.

Held, D., 1997. Democracy and Globalization. Global Governance, 3, 251-267.

International Energy Agency, 2006. World Energy Outlook 2006. Paris. Available from: http://www.iea.org/textbase/nppdf/free/2006/weo2006.pdf [Accessed May 2008].

IPCC, 2007a. Climate Change Impacts, Adaptation and Vulnerability - Summary for Policymakers. In: Solomon, S., Qin, D., Manning, M., Chen, Z., Marquis, M., Averyt, K. B., Tignor, M. \& Miller, H. L., eds. Climate Change 2007: Climate Change Impacts, Adaptation and Vulnerability. Contribution of Working Group II to the Fourth Assessment Report of the Intergovernmental Panel on Climate Change Cambridge: Cambridge University Press.

IPCC, 2007b. Mitigation of Climate Change - Summary for Policymakers. In: Metz, B., Davidson, O. R., Bosch, P. R., Dave, R. \& Meyer, L. A., eds. Climate Change 2007: The Physical Science Basis. Contribution of Working Group III to the Fourth Assessment Report of the Intergovernmental Panel on Climate Change Cambridge: Cambridge University Press.

Kant, I., 1965. The Metaphysical Elements of Justice. Indianapolis: Bobbs-Merrill Co.

Kavuncu, Y. O. \& Knabb, S. D., 2005. Stabilizing greenhouse gas emissions: Assessing the intergenerational costs and benefits of the Kyoto Protocol. Energy Economics, 27 (3), 369-386.

Klosko, G., 2005. Political obligations. Oxford: Oxford University Press.

Maltais, A., 2008. Global Warming and Our Natural Duties of Justice: A cosmopolitan political conception of justice. Uppsala: Acta Universitatis Upsaliensis. Available from: http://www.diva-portal.org/diva/getDocument?urn_nbn_se_uu_diva-86812 fulltext.pdf.

Miller, D., 1995. On Nationality. Oxford: Oxford University Press.

Nagel, T., 1991. Equality and Partiality. Oxford: Oxford University Press.

Nagel, T., 2005. The Problem of Global Justice. Philosophy and Public Affairs, 33 (2), 113 147.

Nordhaus, W. D., 2007. The Challenge of Global Warming: Economic Models and Environmental Policy [online]. New Haven, CT, Yale University. Available from: http://aida.econ.yale.edu/ nordhaus/homepage/dice_mss_091107_public.pdf [Accessed 20 April, 2008].

Nozick, R., 1974. Anarchy, State, and Utopia. New York: Basic Books. 
Okin, S. M., 1989. Justice, gender, and the family. New York: Basic Books.

Osiander, A., 2001. Sovereignty, International Relations, and the Westphalian Myth. International Organization, 55 (2), 251-87.

Ostrom, E., 1990. Governing the Commons: The Evolution of Institutions for Collective Action. Cambridge: Cambridge University Press.

Page, E., 1999. Intergenerational Justice and Climate Change. Political Studies, 47 (1), 53-66.

Page, E., 2006. Climate change, justice and future generations. Cheltenham: Edward Elgar.

Parfit, D., 1984. Reasons and persons. Oxford: Clarendon Press.

Philpott, D., 2001. Sovereignty. In: Zalta, E. N., ed. The Stanford Encyclopaedia of Philosophy (Summer 2003 Edition). Available from: http://plato.stanford.edu/entries/sovereignty/\#3 [Accessed 07 May, 2008].

Pogge, T., 1992. Cosmopolitanism and Sovereignty. Ethics, 103 (October), 48-75.

Rawls, J., 1999a. The Law of Peoples. Cambridge, MA: Harvard University Press.

Rawls, J., 1999b. A Theory of Justice: Revised Edition. Cambridge, MA: Harvard University Press.

Reiman, J., 2007. Being Fair to Future People: The Non-Identity Problem in the Original Position. Philosophy \& Public Affairs, 35 (1), 69-92.

Risse, M., 2006. What to Say about the State. Social Theory and Practice, 32 (4), 671-698.

Sandler, T., 2004. Global Collective Action. Cambridge: Cambridge University Press.

Scanlon, T. M., 1998. What we Owe to Each Other. Cambridge, MA: Harvard University Press.

Simmons, A. J., 1979. Moral principles and political obligations. Princeton, N.J.: Princeton University Press.

Stern, N., 2007. The Economics of Climate Change: The Stern Review. Cambridge: Cambridge University Press.

Sunstein, C. R., 2007. Montreal and Kyoto: A Tale of Two Protocols. Harvard Environmental Law Review, 31 (1), 1-65.

Waldron, J., 1993. Special Ties and Natural Duties. Philosophy and Public Affairs, 22 (1), 330 .

Wellman, C. H., 2001. Toward a Liberal Theory of Political Obligation. Ethics, 111 (4), 735759.

Wellman, C. H., 2004. Political Obligation and the Particularity Requirement. Legal Theory, $10(2), 97-115$.

Wissenburg, M., 2006. Liberalism. In: Dobson, A. \& Eckersley, R., eds. Political theory and the ecological challenge. Cambridge: Cambridge University Press. 